\title{
Traditional and Emerging Techniques for Practical Random Vibration Analyses
}

LB Ryon Chair in Engineering
Rice University
Houston, Texas
USA

PD Spanos
The paper focuses on available tools for conducting random vibration analyses for practical engineering problems. An inherent aspect of this theme is the simultaneous existence of elements with linear behavior, and of elements with nonlinear behavior within the system. In this regard, techniques both for linear and nonlinear random vibration analyses are discussed. Attention is focused on traditional techniques such as statistical linearization, and Monte Carlo simulation. Further, emerging techniques, such as wavelets, as a tool for signal and response localization; and fractionalcalculus, as a tool for capturingnon-localbehaviorare discussed. Pertinent examples of the application are considered.

\section{INTRODUCTION}

Several tools and concepts are necessary for the development of a formalism enabling the capturing and description of uncertainty in the context of random vibration analysis. These must be supplemented by traditional concepts of a vibration analysis such as impulse response function, in the time domain; and transfer function, in the frequency domain. The combination of the probabilistic formalism and of the "solution machinery" of vibrations theory lead to celebrated results such as the relationship between the power spectrum of the input, the power spectrum of the output, and the modulus of the transfer function of a vibratory system. For nonlinear random vibration analysis, these concepts can be extended by using perturbation techniques and generalized tools such as the Wiener-Volterra representation for the response of nonlinear dynamical systems.

\section{RANDOM VIBRATION ANALYSES}

Beyond the classical formalism of linear random vibration analysis, four (4) additional tools are discussed within the context of traditional and emerging solution techniques.

First, the concept of statistical linearization is discussed as a tool for conducting random vibration analysis of nonlinear systems. The fundamental concept of the method is the replacement of the nonlinear dynamical system by a surrogate (equivalent) linear system which lends itself to treatment by the standard input/output relationships mentioned above. This replacement is conducted by determining a set of parameters (equivalent linear stiffness and equivalent linear damping) which minimize in a stochastic sense an appropriate measure of the error between the outputs of the linear and nonlinear systems. Further, invoking a

Received: May 2014, Accepted: November 2014

Correspondence to: PD Spanos

Rice University, Houston, Texas

USA

E-mail: spanos@rice.edu

doi:10.5937/fmet1404265S

(C) Faculty of Mechanical Engineering, Belgrade. All rights reserved reasonable approximation for the system response statistics, the elements of the equivalent linear system are determined by quite convenient formulas. In this particular version, the method of statistical linearization has proved as a quite versatile tool for conducting random analysis for multi-degree-of-freedom systems encountered in engineering practice which are exposed to either stationary or non-stationary excitations, and which exhibit either elastic or inelastic (hysteretic) nonlinearities.

Secondly, and from a certain perspective in conjunction with the concept of the evolutionary power spectrum, the possibility for temporal and spatial localization offered by the wavelets families is discussed. In this context, it is emphasized that many natural phenomena, for instance earthquakes, exhibit frequency content which is changing in time. In this regard, the notion that wavelets can be construed as a "mathematical microscope" is pointed out. They can be viewed as a two-parameter version of the classical Fourier series expansion involving parameters reflecting translation and dilation in the time domain. This eventually affords the representation of the unfolding characteristic of a particular signal both in time and frequency. Various families of wavelets are considered. Further, issues and solution procedures pertaining to the response of linear and nonlinear oscillatory systems exposed to random processes with evolutionary spectra represented via the wavelet transform are discussed.

Thirdly, the concept of fractional (better, noninteger) order derivatives is introduced as a tool for capturing local effects for vibratory systems excitations and responses. In this regard, the fractional derivative of an arbitrary signal is construed, under appropriate conditions, as the inverse transform of the product of the Fourier of the original signal with an arbitrary power of the imaginary axis frequency. From another perspective, it is emphasized that in the discrete domain the fractional order derivative is calculated $\backslash$ as a linear superposition of previous values of the signal with weights decreasing away from the current point of definition of the derivative. In this context, fractional calculus offers the feature of a representation with "nonlocal" and "fading memory" characteristics. This modeling has proved fruitful in several fields, and 
appropriate tools have been developed for conducting random vibration analysis of dynamic systems endowed with fractional derivative terms which are exposed to stochastic excitation. It is emphasized that appending a fractional derivative term in the equation of motion of a dynamic system alters both its stiffness and its damping characteristics.

Fourthly, the possibility of encountering randomness in vibratory systems, not only in terms of the excitation, but also in terms of the characteristics of the vibratory system is noted. In this regard, and with emphasis on continuous vibratory systems, uncertainty quantification is discussed within the framework of the Stochastic Finite Element Method (SFEM). In this context, it is noted that a particular representation of the randomness of the continuous afforded by the classical KarhunenLoéve expansion is particularly expeditious for finite element analyses.

\section{DISCUSSION AND CONCLUSION}

Finally, the technique of Monte Carlo simulation is discussed. This is a particularly versatile technique which applies to systems with either deterministic or random parameters, and either deterministic or random excitations. Practically, a statistical population or relevant system responses is generated, in a sense of a "computational laboratory", by sampling from distributions which describe the parameters defining the dynamics systems and its excitation. Obvious relevant issues regarding the synthesis/simulation of random deviates and stochastic processes with specified probability densities are addressed. Further, attention is focused on the problem of generating stationary and non-stationary random processes samples which are compatible with a target power spectrum (stationary or non-stationary). In this context, the significant drawback of the computational burden associated with the repetitive calculations involved in Monte Carlo techniques is pointed out. Nevertheless, it is also noted that it is the most versatile solution tool for any dynamic system which is defined in a stochastic setting.

\section{REFERENCES}

[1] Boggess, Albert and Francis J. Narcowich, "A First Course in Wavelets with Fourier Anslysis," Prentice-Hall, Inc., New Jersey, 2001

[2] Cohen, Leon, "Time-Frequency Analysis," Prentice Hall Signal Processing Series, Prentice Hall, Inc., New Jersey, USA, 1995.

[3] Crandall, SH and William, DM, "Random Vibration in Mechanical Systems," Massachusetts Institute of Technology (MIT), Cambridge, Massachusetts, Academic Press, New York, 1973.

[4] Fishman, George S., Monte Carlo: Concepts, Algorithms, and Applications," Springer Series in Operations Research, Springer-Verlag New York, Inc., 1996.

[5] Gardiner, CW, "Handbook of Stochastic Methods for Physics, Chemistry and the Natural Sciences,"2nd Edition, 4th Printing, SpringerVerlag Berlin Heidelberg, Germany, 1983, 1985, 1997.
[6] Ghanem, RG and Spanos, PD, "Stochastic Finite Elements: A Spectral Approach," Revised Edition, Dover Publications, Inc., New York, 1991.

[7] Grigoriu, M., "Stochastic Calculus with Applications in Science and Engineering," Birkhäuser-Verlag, New York, 2014.

[8] Lin, YK, "Probabilistic Theory of Structural Dynamics," Robert E. Krieger Publishing Company, Malabar, Florida (original), McGrawHill, Inc., New York (reprint), USA, 1967.

[9] Naess, A. and Moan, T., "Stochastic Dynamics of Marine Structures," Cambridge University Press, New York, 2013.

[10] Roberts, JB and Spanos, PD, "Random Vibration and Statistical Linearization," Dover Publications, New York, 2003.

[11] Rubinstein, Reuven Y., "Simulation and the Monte Carlo Method," Wiley Series in Probability and Mathematical Statistics, John Wiley and Sons, Inc., New York, 1981.

[12] Rugh, Wilson J., "Nonlinear System Theory: The Volterra/Weiner Approach," The John Hopkins University Press, Baltimore, MD, 1981.

[13] Samko, Stefan G, Anatoly A. Kilbas and Oleg I. Marichev, "Fractional Integrals and Derivatives: Theory and Applications," Gordon and Breach Science Publishers, Amsterdam, 1993.

[14] Spanos, PD and GI Evangelatos, "Response of a non-linear system with restoring forces governed by fractional derivatives - Time domain simulation and statistical linearization solution," Journal of Soil Dynamics and Earthquake Engineering, Volume 30, pp. 811-821, 2010.

[15] Spanos, PD and IA Kougioumtzoglou, "Harmonic wavelets based statistical linearization for response evolutionary power spectrum determination," Journal of Probabilistic Engineering Mechanics, Volume 27, pp. 57-68, 2012.

[16] Spanos, PD and MG Donley, "Dynamic Analysis of Non-Linear Structures by the Method of Statistical Quadratization," Lecture Notes in Engineering, Springer-Verlag, Berlin, Germany, 1990.

[17] Spanos, PD and BA Zeldin, "Monte Carlo Treatment of Random Fields: A Broad Perspective," Journal of Applied Mechanics (ASME), Volume 51(3), pp. 219-237, 1998.

\section{ТРАДИЦИОНАЛНЕ И НОВЕ ТЕХНИКЕ У АНАЛИЗИ РЕАЛНИХ СЛУЧАЈНИХ ВИБРАЦИЈА}

\section{PD Spanos}

\section{1. Увод}

Овај рад говори о доступним алатима за спровођење анализа случајних вибрација у инжењерским проблемима. Посебан аспект овог рада се бави симултаним постојањем елемената са линеарним 
понашањем и елемената са нелинеарним понашањем унутар система. У том смислу размотрене су технике које се баве анализирањем и линеарних и нелинеарних случајних вибрација. Посебна пажња посвећена је традиционалним техникама као што су статистичка линеаризација и Монте Карло симулација. Осим тога, говори се и о новим технологијама у развоју, као што су таласићи (wavelets) као алату за локализацију сигнала и одговора; и фракционом рачуну, као алату за разумевање локалног понашања. Значајни примери примене су такође размотрени.

Постоји концепт који је неопходно усвојити ради формализма у опису несигурности код анализа случајних вибрација. Он мора бити допуњен са традиционалним концептом о анализи вибрација као што су функција импулсног одговора у времену и преносна функција у фреквентном домену. Комбинација формализма из вероватноће и из решења код теорије вибрација довела је до чувеног резултата као што је веза између спектра улазне снаге и спектра излазне снаге и модул преносне функције вибрационог система. За нелинеарну анализу случајних вибрација, ови концепти могу бити проширени коришћењем технике пертурбације и општих алата као што је Винер-Волтерова презентација одговора нелинеарних динамичких система

\section{2. АНАЛИЗА СЛУЧАЈНИХ ВИБРАЦИЈА}

Изван класичног формализма анализа линеарних случајних вибрација, четири додатна алата су дискутована унутар садржаја традиционалних и новоформираних техника решавања.

Прво, концепт статистичке линеаризације је дискутован као алат за спровођење анализа случајних вибрација нелинеарних система. Основни концепт овог метода је замена вибрационог система са еквивалентним линеарним системом на којем се спроводи третман преко стандардне излазно-улазне везе поменуте изнад. Ова замена је извршена одређивањем скупа параметара (еквивалентна линеарна крутост и еквивалентна линеарна пригушеност) који смањују у стохастичком смислу одговарајућу грешку мерења између излазних вредности код линеарног и нелинеарног система. Такође, позивајуци се на апроксимацију статистике системских одговора, елементи еквивалентног линеарног система су одредјени прилицно једноставним формулама. У овој верзији, метода статистичке линеаризације је потврдјена као врло прилагодљив алат за провођење анализа за системе са више степени слободе који се налазе у инжењерског пракси. Ови системи су излозени стационарним и нестационарним побудама и могу испољавати и еластицна и нееластицна (хистерична) нелинеарна понашања.

Друго, из одређеног угла посматрања, обрађена је могућност временске и просторне локализације коју омогућавају фамилије таласића, имајући при том у виду концепт развојног опсега снаге. У овом контексту, посебно су посматране и многе природне појаве, као што су на пример земљотреси, где се посматра фреквенција узорка у времену. Истакнута је могућност реконструкције кретања од стране таласића као "математичког микроскопа". Они се могу посматрати као дво параметарска верзија класичне Фуријеве трансформације реда који укључује параметре за превод и дилетацију времена. Ово временом омогућава презентацију сигнала и у времену и учесталости. Неколико породица таласица су узети у обзир у овом истраживању. Такође, обрађени су и проблеми и решења процедуре која се односи на одзив линеарних и нелинеарних осцилаторних система који су излозени случајним процесима еволутивног опсега и представљени су преко таласића.

Треће, концепт нецелобројног фракционог реда уводи се као алат за одређивање локалних ефеката почетне побуде и одговора вибрационог система. Тада је фракциони дериват произвољног сигнала који је конструисан под одговарајуцим условима, представљан као инверзна трансформација производа Фоуриеровог оригиналног сигнала са произвољном фреквенцијом снаге у замисљеној оси. Из друге перспективе, наглашено је да у дискретном домену извод фракционог реда се израчунава као линеарна суперпозиција претходних вредности сигнала са тежинама које се смањују од тренутне тачке у дефиницији извода. Тада, фракциони рацун нуди својство представљања са “не-локалним" карактеристикама и карактеристикама са “лошом меморијом”. Моделовање се показало плодоносним у неколико области и одговарајући алати су конструисани за вођење анализа случајних вибрација динамичког система обдареног са фракционим дериватом који су изложени стохастичкој побуди. Истакнуто је да додавање члана за фракциони дериват у једначину кретања динамичког система мења крутост и карактеристике пригушивања.

Четврто, могућност налажења случајности у вибрационим системима, не само у случају првобитне побуде, него и код карактеристика посматраног вибрационог система. У том смислу, обрађена је квантификација неизвесности у окружењу Методе Стохастичких Коначних Елемената (МСКЕ) са нагласном на континуалне вибрационе системе. Примећено је да постоји посебни приказ континуалне случајности коју пружа Кархуенен-Лоева експанзија која је посебно проширива за анализе коначних елемената.

\section{3. ДИСКУСИЈА И ЗАКЉУЧАК}

У закључку напомињемо да је и техника Монте Карло симулације размотрена. Ово је посебно прилагодљива техника која се може применити на системе са обоје и детерминистичким и случајним параметрима и побудама. Статистичка генерација релевантних одговора система је генерисана у “рачунарској лабораторији”, тако што су узети узорци из расподела која описије параметре динамичког система и почетна побуда. Посебно су продискутовани очигледни проблеми у вези синтезе 
и симулације случајних одступања и стохастицких процеса са одређеном густином расподеле. Такође, пажња је посвећена проблему генерисања узорка из стационарних и нестационарних случајних процеса који одговарају жељеном опсегу снаге (стационарном или нестационарном). У овом смислу, посебно је истакнута препрека у рачунарском терету у вези са репетитивним израцунавањима у Монте Карло техници. Упркос томе, примећено је да је ово решење најприлагодљивија опција за било који динамицки систем који је дефинисан у стохастицкој поставци. 